\title{
Impact Assessment of Plant Growth Promoting Rhizobacteria on Growth and Nutrient Uptake of Maize (Zea mays)
}

\section{Attique Ahmed ${ }^{1}$, Tariq Sultan ${ }^{1}$, Ghulam Qadir ${ }^{2}$, Obaid Afzal2*, Mukhtar Ahmed ${ }^{5}$, Shamim-U1-Sibtain Shah $^{3}$, Muhammad Asif ${ }^{4}$, Safdar $\mathrm{Ali}^{2}$ and Muhammad Zeeshan Mehmood ${ }^{2}$}

${ }^{1}$ Land Resource Research Institute, National Agriculture Research Center, Islamabad, Pakistan; ${ }^{2}$ Department of Agronomy, Pir Mehr Ali Shah Arid Agriculture University, Rawalpindi, Pakistan; ${ }^{3}$ Farm Operation Services, National Agriculture Research Center, Islamabad, Pakistan; ${ }^{4}$ Planning and Development Division, Pakistan Agricultural Research Council, Islamabad, Pakistan; ${ }_{5}^{5}$ Department of Agricultural Research for Northern Sweden, Swedish University of Agricultural Sciences Umea 90183 Sweden.

Abstract | Plant growth promoting rhizobacteria (PGPR) promote crop growth and seed yield. However, in farm management practices genotype and environmental conditions may also affect the growth and nutrient uptake. PGPR and phosphate solubilizing bacteria (PSB) in combination with synthetic fertilizers can enhance crop productivity and soil fertility. Present experiment aimed to investigate the effect of PGPR and PSB inoculation with $\mathrm{T}_{1}$ Control (Recommended NP), $\mathrm{T}_{2}$ (PGPR-1 + PSB + 3/4 N + 3/4 P), $\mathrm{T}_{3}(\mathrm{PGPR}-2+\mathrm{PSB}$ $+3 / 4 \mathrm{~N}+3 / 4 \mathrm{P}), \mathrm{T}_{4}(\mathrm{PGPR}-3+\mathrm{PSB}+3 / 4 \mathrm{~N}+3 / 4 \mathrm{P}), \mathrm{T}_{5}(\mathrm{PGPR}-4+\mathrm{PSB}+3 / 4 \mathrm{~N}+3 / 4 \mathrm{P}), \mathrm{T}_{6}(\mathrm{PGPR}-5+\mathrm{PSB}+3 / 4$ $\mathrm{N}+3 / 4 \mathrm{P}), \mathrm{T}_{7}(\mathrm{PGPR}-1,2,3,4,5+\mathrm{PSB}+3 / 4 \mathrm{~N}+3 / 4 \mathrm{P}$ ). The inoculation of PGPR + PSB at $75 \%$ (T5 and T7) significantly increased chlorophyll content, no. of leaves, plant height, ear leaf area, ear inter nodes girth, flag leaf area over $\mathrm{T}_{1}$ in pot experiment. Similarly, the inoculation of PGPR + PSB with $\mathrm{T}_{2}$ and in combination with $\mathrm{T}_{1}$ also at $75 \%$ of recommended NP significantly increased chlorophyll content, no. of leaves, plant height, ear leaf area, ear inter nodes girth, flag leaf area over control in the field experiment. Inclusion of PGPR and PSB significantly increase grain and straw $\mathrm{P}$ contents as well as positively enhance soil nitrogen and phosphorus compared to $\mathrm{T}_{1}$ treatment. Present results implied that PGPR and PSB inoculation is a plausible strategy for increasing the nutrient availability to maize, and therefore an important tool to increase maize production under prevailing conditions.

Received | April 16, 2018; Accepted | December 24,2019; Published | April 20, 2020

*Correspondence | Obaid Afzal, Department of Agronomy, Pir Mehr Ali Shah Arid Agriculture University, Rawalpindi, Pakistan; Email: obaid1052@gmail.com

Citation | Ahmed, A., T. Sultan, G. Qadir, O. Afzal, M. Ahmed, S.S. Shah, M. Asif, S. Ali and M.Z. Mehmood. 2020. Impact assessment of plant growth promoting rhizobacteria on growth and nutrient uptake of maize (Zea Mays). Pakistan Journal of Agricultural Research, 33 (2): $234-246$. DOI | http://dx.doi.org/10.17582/journal.pjar/2020/33.2.234.246

Keywords | Maize, Nutrient Uptake, PGPR, Growth, Development

\section{Introduction}

$\mathrm{M}$ aize (Zea mays L.) is the member of family Poaceae (Gramineae) and is widely grown worldwide. Humans and livestock are dependent on maize for food. Its grain contains starch, protein, oil, fiber, sugar and ash having percentage of $72 \%, 10 \%$, $4.8 \%, 8.55 \%, 3.05 \%$ and $1.7 \%$ respectively. Its total annual production is 3.7 million tons per 0.9 million hectares (Chaudhry, 1983; Haji et al., 2008). Primarily low fertile lands are responsible for its low production while the input of man-made fertilizers can significantly increase the yield simultaneously causing the environmental problems which are injurious to living beings and to surroundings in terms of runoff, leaching, eutrophication and emission of nitrogen in aquatic ecosystems (Adesemoye and Kloepper, 2009; Flessa et al., 2002; Glick and Pasternak, 2003; Hussain et al., 2009; Vessey, 2003; Yang et al., 2009). Distance between production and exploitation of June 2020 | Volume 33 | Issue 2 | Page 234 
maize can be improved by application of bio and chemical fertilizers. Moreover, the use of bio-fertilizer with low doses of synthetic fertilizers can avoid the negative effects of chemical fertilizers. Such holistic approach is feasible and responsive to environment (Altomare et al., 1999). PGPR enhance the nutrient uptake by the plants and inoculation reduces the use of chemical fertilizers (Cakmakçi et al., 2006). PGPR enhance crop growth by colonizing roots which has significant effect on development of crop plant (Kloepper et al., 1980; Wu et al., 2005). Chemical secretions of PGPR in rhizosphere have potential to enhance crop productivity (Cherif et al., 2018) even under stressed environments (Choudhary and Varma, 2016) through a number of biogeochemical processes such as solubilization of inorganic compounds and mineralization in soil Van Der Heijden et al. (2008). Plant growth promoting rhizobacteria enhances growth in terms of emergence and weight of newly germinated plants, vigor, improvement in root system and yield (Khalid et al., 2003). These are proved to be one of the potent alternatives to synthetic fertilizer during last two decades and are widely accepted in silviculture and horticulture as eco-friendly component (Kumari et al., 2019).

Growth of plants is being enhanced by PGPRs through different physiochemical processes such as hormones production, development of stress resistance, fixation of atmospheric nitrogen, mobilization and solubilization of nutrients and suppression of root pathogens (Rodri冈guez and Fraga, 1999; Sindhu et al., 1999) which result in an increased supply of primary nutrients to host plant (Wu et al., 2005). Ecological niches on roots are being colonized by rhizobacteria, which competes root micro flora, and are responsible for some vital mechanisms in soil such as utilization and mineralization of nutrients and denitrification of rhizo-micro flora (Antoun, 2001; Pradhan and Sukla, 2006). Although the beneficial effects of the symbiotic association of rhizobia with legume plants is known, these bacteria are not considered PGPR, except when associated with non-legume plants (Dobbelaere et al., 2003). Growth of non-legumes such as radish and rice are improved by $\mathrm{N}_{2}$ fixing bacteria and Rbizobium strains (Antoun et al., 1998; Mirza et al., 2006) and minimizes use of $\mathrm{N}$-based chemical fertilizers (Bhattacharjee et al., 2008). Non-symbiotic $\mathrm{N}_{2}$ fixing rhizospheric bacteria belonging to genera including Azoarcus, Azospirillum, Burkbolderia, Gluconacetobacter and Pseudomonas (Bashan and De-Bashan, 2010;
Estrada-De Los Santos et al., 2001; Fuentes-Ramírez et al., 2001; Mirza et al., 2006; Reinhold-Hurek et al., 1993) have been isolated from different soils and used for growth and yield of different crops.

Phosphorus is an essential plant nutrient, which is mostly present in unavailable form in the soils. The plant cannot uptake the phosphorus for optimum growth and ultimately results in the reduced yield. There are microorganisms having ability to solubilize the phosphorus and make it available to the plants for their optimum growth. PGPR and phosphate solubilizing bacteria (PSB) make available balanced nutrition to crop plants (Belimov et al., 1995). PGPR substances improves plant growth and PSB facilitate uptake of nutrients from the rhizosphere soil (Fuhrmann and Wollum, 1989). Under nutrient limiting conditions presences of rhizo-bacteria possibly significantly increase the plant growth and yield have been discussed for many years (Jha et al., 2009). PGPR helps in plant growth in many ways; they promote growth of plant by production of growth hormones like auxins, gibberellins, cytokinins etc. which help in cell elongation and cell division. Production of siderophores and provision of iron to plants, fixation and availability of nitrogen to plants, Solubilization of minerals such as phosphorus and Zinc and produce enzymes that can significantly increase systemic resistance against different pathogens (Patten and Glick, 1996). PGPR containing1-aminocyclopropane-1-carboxylate (ACC)-deaminase enhances the growth, yield, and salt tolerance of maize grown on salt-affected fields (Nadeem et al., 2009). Despite the great importance of plant growth promoting rhizobacteria for nitrogen fixation and phosphorous solubilization in nonlegumes, small work had been done with regard to inoculation of PGPR followed by low fertilizer application. Thus present experiment was undertaken to assess the responsive potential of maize to PGPR inoculation followed by reduced fertilizer input with reduce fertilizer application on growth and development, uptake of nutrients and yield of maize.

\section{Materials and Methods}

A pot and field experiments were conducted at the National Agricultural Research Center (NARC) Islamabad ( $\left.38^{\circ} 78^{\prime \prime N}, 73^{\circ} 57^{\prime} \mathrm{E}\right)$. Strains of PGPR were tested in pot and field experiments for maize during August-December 2011. For pot experiment soil was 
collected from the cultivated field, homogenized, ground and filled in $8 \mathrm{~kg}$ capacity pots for different treatment application. Recommended fertilizer rate $80 \mathrm{~N}, 50 \mathrm{P}_{2} \mathrm{O}_{5}, 50 \mathrm{~K}_{2} \mathrm{O} \mathrm{mg} \mathrm{kg}{ }^{-1}$ soil were applied in the pot following completely randomized design with three replications. Field experiment was conducted following Randomized complete block design with three replications. Recommended dose of 160 N, 90 $\mathrm{P}_{2} \mathrm{O}_{5}, 90 \mathrm{~K}_{2} \mathrm{O} \mathrm{kg} \mathrm{ha}{ }^{-1}$ was applied in the field while $\mathrm{N}$ was applied in split doses at sowing and silking stage in both experiments.

\section{Preparation of cultures}

Bacterial cultures were prepared in respective media (Luria Broth for PGPR and Pikoviskia for PSB (Lavakush et al., 2012) pH of culture was maintained at 6.8-7.0 (Table 1).

Table 1: Luria broth media preparation.

$\begin{array}{ll}\text { Chemicals } & \text { Quantity (g/liter) } \\ \text { Yeast Extract } & 5 \\ \text { Tryphtone } & 10 \\ \mathrm{NaCl} & 5 \\ \text { Agar } & 18 \\ \text { Distilled Water } & 1000 \mathrm{ml} \\ \text { Pikoviskia Media Preparation } & \\ \text { Chemicals } & \text { Quantity (g/liter) } \\ \mathrm{Ca}_{3}\left(\mathrm{PO}_{4}\right)_{2} & 3 \\ \mathrm{Sucrose} & 10 \\ \left(\mathrm{NH}_{4}\right)_{2} \mathrm{SO}_{4} & 0.5 \\ \mathrm{NaCl} & 0.2 \\ \mathrm{MgSO}_{4} \cdot 7 \mathrm{H}_{2} \mathrm{O} & 0.1 \\ \mathrm{KCL} & 0.2 \\ \mathrm{Yeast} \mathrm{extracts}_{\mathrm{MnSO}_{4}} & 0.5 \\ \mathrm{FeSO}_{4}(\mathrm{Fe}-\mathrm{EDTA}) & \text { Trace } \\ \mathrm{CaCO}_{3} & 0.1 \\ \mathrm{Agar}^{\mathrm{Distilled} \mathrm{Water}} & 0.3 \\ \end{array}$

Treatments/microorganisms combination for pot experiment: T1 Control (Recommended NP); T2 PGPR-1 + PSB + 3/4 N + 3/4 P; 3 PGPR-2 + PSB $+3 / 4 \mathrm{~N}+3 / 4 \mathrm{P} ; \mathrm{T} 4 \mathrm{PGPR}-3+\mathrm{PSB}+3 / 4 \mathrm{~N}+3 / 4 \mathrm{P} ; \mathrm{T} 5$ PGPR-4 + PSB + 3/4 N + 3/4 P; T6 PGPR-5 + PSB + $3 / 4 \mathrm{~N}+3 / 4 \mathrm{P} ;$ T7 PGPR-1, 2, 3, 4, $5+\mathrm{PSB}+3 / 4 \mathrm{~N}+3 / 4 \mathrm{P}$.

Treatments/microorganisms combination for field experiment: Treatments were as follow: T1 Control (Recommended NPK); T2 PGPR+ PSB + 3/4 N + 3/4
P; T3 PGPR + PSB+ (Recommended NPK).

\section{Crop parameters}

Chlorophyll content was measured using chlorophyll meter (SPAD, 502) and the average was calculated at 45 DAS. Number of leaves, ear leaf area $\left(\mathrm{cm}^{2}\right)$, ear internode girth $(\mathrm{mm})$, flag leaf area $\left(\mathrm{cm}^{2}\right)$ and plant height $(\mathrm{cm})$ at maturity were recorded.

\section{Physio-chemical analysis of the soil}

Collected soil samples were analyzed for texture, $\mathrm{pH}$, nitrate $\mathrm{N}\left(\mathrm{mg} \mathrm{kg}^{-1}\right)$, available $\mathrm{P}, \mathrm{K}\left(\mathrm{mg} \mathrm{kg}{ }^{-1}\right)$ and EC ( $\mathrm{dSm}-1)$ by the Ammonium Bicarbonatediethylenetriaminepentaacetic Acid (AB-DTPA) method. Sol texture was determined by ISSS triangle (Table 2). (Gee and Bauder, 1986).

\section{Plant analysis}

Oven dried samples were kept at $70^{\circ} \mathrm{C}$ for 24 hours, grounded parts were stored in moisture free bags.

\section{Table 2: Physico-Chemical analysis of the soil samples from experimental site.}

\begin{tabular}{|c|c|c|}
\hline \multirow[t]{2}{*}{ Parameters } & \multicolumn{2}{|c|}{ Amounts } \\
\hline & Pot & Field \\
\hline $\mathrm{NO}_{3}-\mathrm{N} \mathrm{mg} \mathrm{kg}{ }^{-1}$ & 0.95 & 0.98 \\
\hline Available $\mathrm{P}$ mg kg${ }^{-1}$ & 1.02 & 0.97 \\
\hline Available K (extractable) $\mathrm{mg} \mathrm{kg}^{-1}$ & 105 & 110 \\
\hline Electrical Conductivity (EC) $\mathrm{dS} \mathrm{m}^{-1}$ & 0.15 & 0.13 \\
\hline $\mathrm{pH}$ & 7.5 & 7.6 \\
\hline Particle size analysis (textural class) & Loam & Loam \\
\hline
\end{tabular}

\section{Plant phosphorous}

Finely ground plant samples $(0.25 \mathrm{~g})$ were taken in the conical flask, $10 \mathrm{ml}$ of both acid (perchloric and nitric acid in 2:1) was added. These flasks were heated on a hot plate at $100-300{ }^{\circ} \mathrm{C}$ till the samples solution (about 2-3 ml) was colorless. Flasks were taken away from hot plates and allowed to cool. The digest was transmitted into a $50 \mathrm{ml}$ volumetric flask and volume $(50 \mathrm{ml})$ was completed with distilled water. Five $\mathrm{ml}$ extract and $5 \mathrm{ml}$ color developing reagent (ammonium molybdate + ammonium vanadate + nitric acid) was mixed in test tube for phosphorus assessment. The tubes were blended in a mechanical stirrer. The readings were noted on spectrophotometer at $470 \mathrm{~nm}$ (Ryan et al., 2007). 
Statistical analysis

The data was statistically analyzed by using Statistix 8.1 and evaluated by using Fisher`s Least Significant Difference (LSD) Test (Steel and Torrie, 1980).

\section{Results and Discussion}

\section{Effect of PGPR on growth and nutrient uptake of maize} in pot experiment

SPAD chlorophyll content: Chlorophyll content of maize enhanced significantly $(\mathrm{P}<0.05)$ up to 9\% by inoculation of PGPR-(Mix) and PSB where nitrogen and phosphorus was applied @ 60 and 37.5 $\mathrm{mg} \mathrm{kg}{ }^{-1}$ compared to control (Recommended N 80 and $\mathrm{P} 50 \mathrm{mg} \mathrm{kg}{ }^{-1}$ ) (Figure 1). The inoculation of different strains of PGPR and PSB with nitrogen and phosphorus (@60 and $37.5 \mathrm{mg} \mathrm{kg}{ }^{-1}$ ) showed significant increase in chlorophyll content of maize over control Recommended N 80 and P $50 \mathrm{mg} \mathrm{kg}^{-1}$. The inoculation of different strains of PGPR and PSB with reduced levels of (Recommended 60 and 37.5 $\mathrm{mg} \mathrm{kg}{ }^{-1}$ ) significantly enhanced the Total Chlorophyll of the maize over the control recommended NP respectively (Table 3 ).

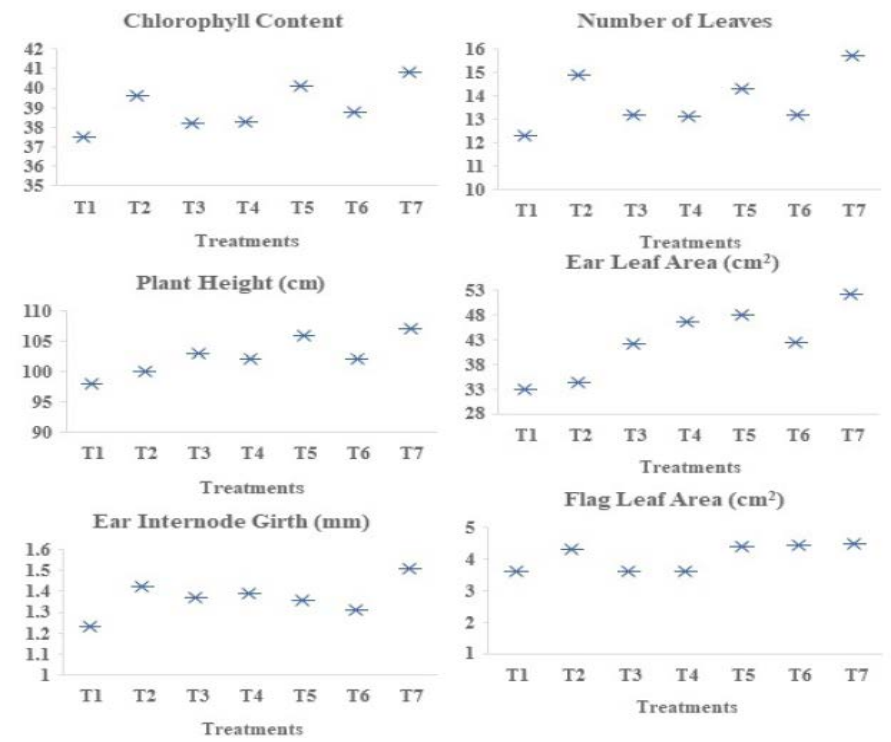

Figure 1: Effect of plant growth promoting Rhizobacteria on Agro-physiological traits of maize in pot experiment.

\section{Number of leaves per plant}

Number of leaves per plant were significantly different $(\mathrm{P}<0.05)$ between the treatments with $\mathrm{co}^{-}$ inoculation of PGPRs and PSB with N and P @ 60 and $37.5 \mathrm{mg} \mathrm{kg}^{-1}$ recording the highest $27 \%$ increase in the number of leaves per plant with PGPR-(Mix) over control (Recommended N 80 and P 50 mg kg-1) (Figure 1). PGPR-1 and PSB inoculation with $\mathrm{N}$ and
P@ 60 and $37.5 \mathrm{mg} \mathrm{kg}^{-1}$ improved number of leaves per plant at maturity to $18 \%$ over control (Table 3 ). Whereas, inoculation of PGPR-2, PGPR-5 and PGPR -3 showed similar results.

\section{Plant height}

Maximum plant height was recorded by the application of PGPR-(Mix) and PSB with nitrogen and phosphorus applied @ 80 and P $50 \mathrm{mg} \mathrm{kg}^{-1}$ that was $8 \%$ higher compared to control (Recommended $\mathrm{N} 80$ and $\mathrm{P} 50 \mathrm{mg} \mathrm{kg}^{-1}$ ) (Figure 1). Inoculation of PGPR-4 and PSB with N and P @ 60 and $37.5 \mathrm{mg} \mathrm{kg}$ $\left.{ }^{1}\right)$ was $7 \%$ higher over control (Table 3). Furthermore, simultaneous inoculation of all PGPR strains and PSB with low levels of nitrogen and phosphorus (@ 60 and $37.5 \mathrm{mg} \mathrm{kg}^{-1}$ ) was significantly higher over recommended NP respectively.

\section{Ear leaf area $\left(\mathrm{cm}^{2}\right)$}

The data on ear leaf area indicate significant difference $(\mathrm{P}<0.05)$ in co-inoculation of PSB and PGPR-(Mix) with N and P @ 60 and $37.5 \mathrm{mg} \mathrm{kg}{ }^{-1}$ that was 55\% higher over control (Recommended $\mathrm{N} 80$ and $\mathrm{P} 50 \mathrm{mg} \mathrm{kg}^{-1}$ ) (Figure 1). Inoculation of PGPR-4 and PSB with nitrogen and phosphorus (@ 60 and $37.5 \mathrm{mg} \mathrm{kg}^{-1}$ ) showed 41\% increase over control (Recommended N 80 and P $50 \mathrm{mg} \mathrm{kg}{ }^{-1}$ ) (Table 3). Similarly, inoculation of PGPRs and PSB at reduced levels of nitrogen and phosphorus (@ 60 and $37.5 \mathrm{mg} \mathrm{kg}^{-1}$ ) was significantly higher over recommended NP.

\section{Ear internodes girth ( $\mathrm{mm}$ )}

Maximum ear internodes girth was recorded in case of simultaneous application of PGPR-(Mix) and PSB with $\mathrm{N}$ and $\mathrm{P} @ 60$ and $37.5 \mathrm{mg} \mathrm{kg}{ }^{-1}$ that was 21\% higher over control (Recommended N 80 and P $50 \mathrm{mg} \mathrm{kg}^{-1}$ ) (Figure 1). Co-inoculation of PGPR1 and PSB with $\mathrm{N}$ and $\mathrm{P} @ 60$ and $37.5 \mathrm{mg} \mathrm{kg}^{-1}$ ) showed 16\% increase than control (Recommended $\mathrm{N} 80$ and $\mathrm{P} 50 \mathrm{mg} \mathrm{kg}^{-1}$ ). Inoculation of PGPRs and PSB with $\mathrm{N}$ and $\mathrm{P} @ 60$ and $37.5 \mathrm{mg} \mathrm{kg}^{-1}$ improved ear internodes girth compared to control (Table 3).

\section{Flag leaf area $\left(\mathrm{cm}^{2}\right)$}

The data on flag leaf area indicated significant $(\mathrm{P}<$ 0.05) increase in case of co-inoculation of PGPR(Mix) and PSB with N and P @ 60 and $37.5 \mathrm{mg} \mathrm{kg}^{-1}$ that was $31 \%$ higher over control (Recommended $\mathrm{N} 80$ and $\mathrm{P} 50 \mathrm{mg} \mathrm{kg}^{-1}$ ) (Figure 1). Inoculation of 
PGPR-5 and PSB with N and P @ 60 and $37.5 \mathrm{mg}$ $\mathrm{kg}^{-1}$ showed $27 \%$ increase over control (Table 3 ).

\section{Plant analysis after harvest}

Straw phosphorus (\%): A considerable variation in straw phosphorus contents was observed by individual application of PGPR strains with PSB and N and P @ 60 and $37.5 \mathrm{mg} \mathrm{kg}^{-1}$ (Figure 2). Maximum increase in straw phosphorus was recorded by co-inoculation of PGPR-(Mix) and PSB with N and P @ 60 and $37.5 \mathrm{mg} \mathrm{kg}^{-1}$ over control (Recommended N 80 and P $50 \mathrm{mg} \mathrm{kg}^{-1}$ ) (Table 4).

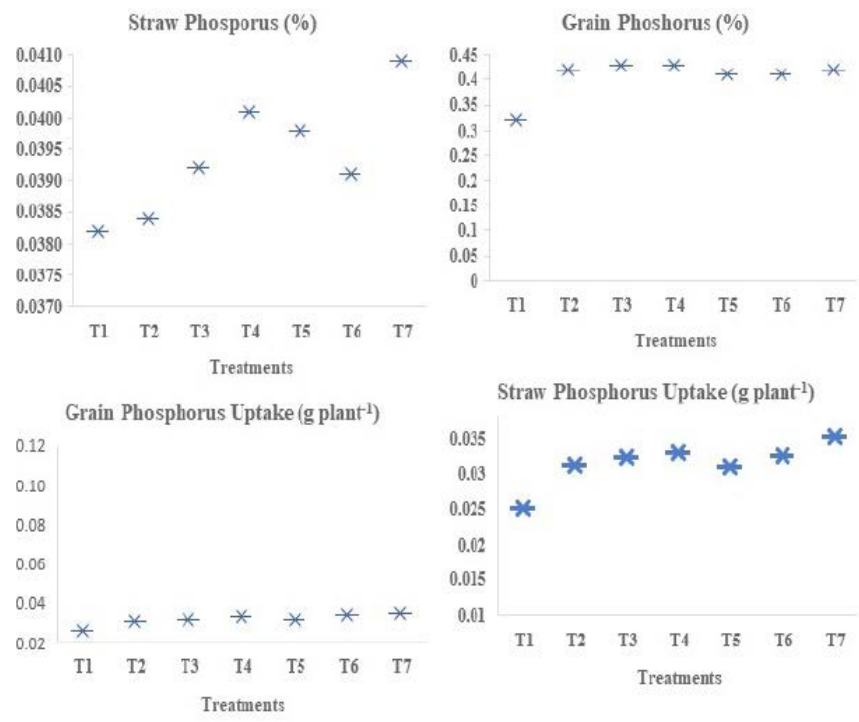

Figure 2: Effect of plant growth promoting Rhizobacteria on contents and uptake of Phosphorous (gm plant- ${ }^{1}$ ) in maize plants in pot experiment.

Grain phosphorus (\%): Like phosphorus content in straw, a significant $(\mathrm{P}<0.05)$ increase in $\mathrm{P}$ content in grain was recorded as compared to control (Recommended N 80 and P $50 \mathrm{mg} \mathrm{kg}^{-1}$ ) was observed in response to combined inoculation of PGPR-(Mix) and PSB where nitrogen and phosphorus was applied @ 60 and $37.5 \mathrm{mg} \mathrm{kg}^{-1}$ (Figure 2). While grain phosphorus contents vary considerably by individual application of PGPR strains with PSB and N and P @ 60 and $37.5 \mathrm{mg} \mathrm{kg}^{-1}$ (Table 4).

Straw phosphorus uptake (gm plant ${ }^{-1}$ ): The results revealed that the straw phosphorus uptake was significantly improved in case of inoculation of PGPR strains with PSB and N and P @ 60 and 37.5 $\mathrm{mg} \mathrm{kg}{ }^{-1}$ over control (Figure 2). Maximum increase in straw phosphorus uptake was observed in case of coinoculation of PGPR-(Mix) and PSB with $\mathrm{N}$ and $\mathrm{P}$ @ 60 and $37.5 \mathrm{mg} \mathrm{kg}^{-1}$ over control (Recommended $\mathrm{N} 80$ and P $50 \mathrm{mg} \mathrm{kg}^{-1}$ ) (Table 4).
Grain phosphorus uptake (gm plant $\left.^{-1}\right)$ : Similarly phosphorus uptake in grain was significantly $(\mathrm{P}<$ $0.05)$ increase in all inoculated pots as compared to control (Recommended N 80 and P $50 \mathrm{mg} \mathrm{kg}-1$ ) (Figure 2). However, highest response was recorded where inoculation of PGPR-(Mix) and PSB with nitrogen and phosphorus @ 60 and $37.5 \mathrm{mg} \mathrm{kg}^{-1}$ was applied (Table 4).

\section{Effect of PGPR on growth and nutrient uptake of} maize in field experiment: Field Experiment was carried out to check the influence of PGPR with varied levels of fertilizers on maize.

SPAD Chlorophyll content: The increase in chlorophyll content of maize is up to $9 \%$ by inoculation of PGPR and PSB where nitrogen and phosphorus was applied @ Recommended N 160 and P $90 \mathrm{~kg} \mathrm{ha}^{-1}$ compared to control (Recommended N 160 and P 90 $\mathrm{kg} \mathrm{ha}{ }^{-1}$ ) (Figure 3). Whereas inoculation of PGPR and PSB with nitrogen and phosphorus @ 120 and P $67.5 \mathrm{~kg} \mathrm{ha}^{-1}$ showed 5\% increase in chlorophyll content of maize over control (Recommended N 160 and $\left.\mathrm{P} 90 \mathrm{~kg} \mathrm{ha}^{-1}\right)$ (Table 5).

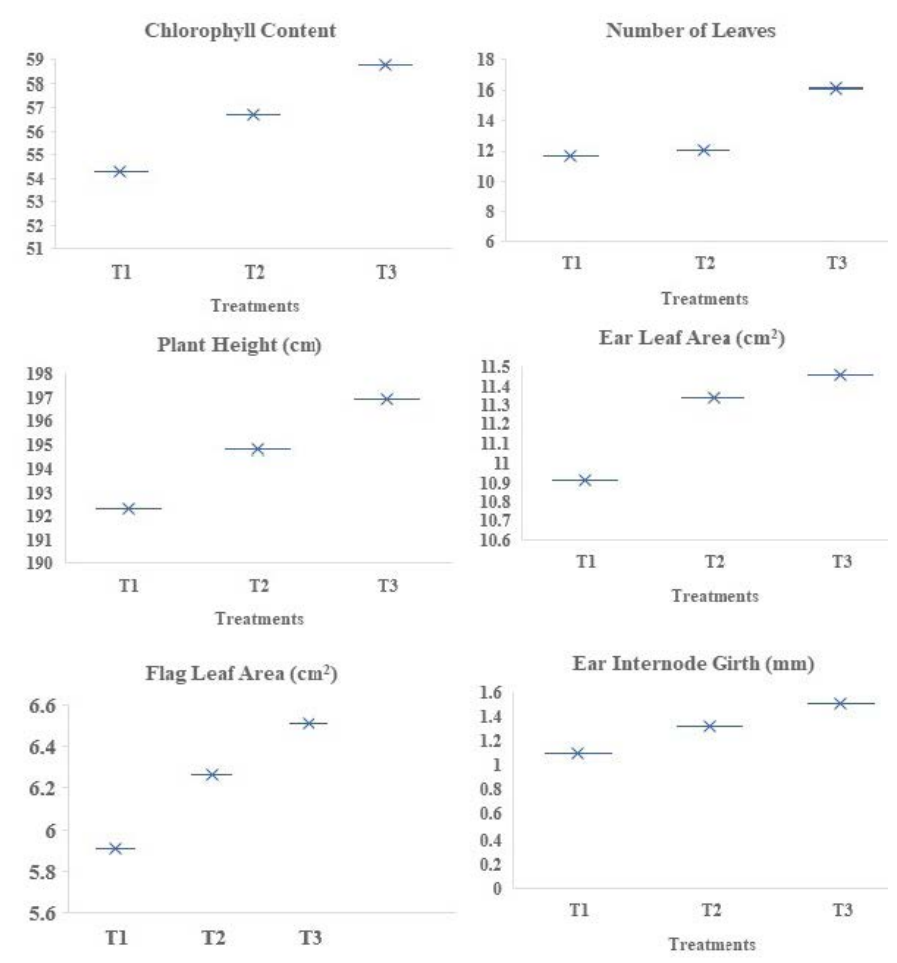

Figure 3: Effect of plant growth promoting Rhizobacteria on Agro-physiological traits of maize in field experiment.

Number of leaves per plant: Number of leaves per plant at maturity showed significant difference $(\mathrm{P}<0.05)$ between the treatment with co-inoculation of PGPR and PSB with recommended $\mathrm{N}$ and P @ 160 and $90 \mathrm{~kg}$ $\mathrm{ha}^{-1}$ recording $45 \%$ increase over control (Recommended 
Table 3: Effect of plant growth promoting rhizobacteria on Agro-physiological traits of maize in pot experiment.

Treatment Chlorophyll \% In- No. of \% In- Plant \% In- Earleaf \% In- Ear inter- \% In- Flagleaf \% InContents crease Leaves crease Height crease area crease node girth crease area crease

T1= Control (Recom- 37.4d ----- $12.33 \mathrm{~d}$----- $98.50 \mathrm{e}-----33.07 \mathrm{~d}$------ $1.22 \mathrm{a} \quad-----3.58 \mathrm{~d}$

mended NP)

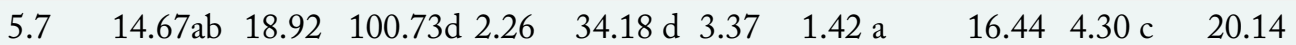

$+3 / 4 \mathrm{~N}+3 / 4 \mathrm{P}$

$\mathrm{T} 3=\mathrm{PGPR}-2+\mathrm{PSB} \quad 38.44 \mathrm{~b}$

$+3 / 4 \mathrm{~N}+3 / 4 \mathrm{P}$

$\begin{array}{llllllllll}2.78 & 13.33 \mathrm{~cd} 8.11 & 103.12 \mathrm{c} & 4.7 & 40.84 \mathrm{c} & 23.49 & 1.37 \mathrm{a} & 10.59 & 3.69 \mathrm{~d} & 2.91\end{array}$

$\mathrm{T} 4=\mathrm{PGPR}-3+\mathrm{PSB} \quad 38.44 \mathrm{bc}$

$2.78 \quad 13.33 \mathrm{~cd} 8.11 \quad 101.52 \mathrm{~d} 3.07 \quad 45.44$ b $37.42 \quad 1.40 \mathrm{a}$

$13.413 .77 \mathrm{~d} \quad 5.12$

$+3 / 4 \mathrm{~N}+3 / 4 \mathrm{P}$

T5= PGPR $-4+\mathrm{PSB} \quad 39.96 \mathrm{ab}$

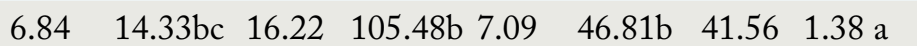

$11.9 \quad 4.44 \mathrm{bc} \quad 23.9$

$+3 / 4 \mathrm{~N}+3 / 4 \mathrm{P}$

T6= PGPR $-5+$ PSB $38.87 \mathrm{bc}$

$3.93 \quad 13.33 \mathrm{~cd} 8.11 \quad 101.58 \mathrm{~d} 3.13$

41.46 c 25.371 .30 a

$6.02 \quad 4.58 \mathrm{ab} \quad 27.93$

$+3 / 4 \mathrm{~N}+3 / 4 \mathrm{P}$

$\mathrm{T} 7=\mathrm{PGPR}-1,2,3,4,40.95 \mathrm{a}$

$5+\mathrm{PSB}+3 / 4 \mathrm{~N}+3 / 4 \mathrm{P}$

$9.49 \quad 15.67$ a $\quad 27.03 \quad 107.02$ a $8.65 \quad 51.44$ a $\quad 55.55 \quad 1.50$ a

$21.794 .72 \mathrm{a}$

31.84

Table 4: Effect of plant growth promoting rhizobacteria on contents and uptake of Phosphorous (gm plant- ${ }^{1}$ ) in maize plants after harvesting in pot experiment.

\section{Treatment}

T1= Control (Recommended NP)

$\mathrm{T} 2=\mathrm{PGPR}-1+\mathrm{PSB}+3 / 4 \mathrm{~N}+3 / 4 \mathrm{P}$

$\mathrm{T} 3=\mathrm{PGPR}-2+\mathrm{PSB}+3 / 4 \mathrm{~N}+3 / 4 \mathrm{P}$

$\mathrm{T} 4=\mathrm{PGPR}-3+\mathrm{PSB}+3 / 4 \mathrm{~N}+3 / 4 \mathrm{P}$

$\mathrm{T} 5=\mathrm{PGPR}-4+\mathrm{PSB}+3 / 4 \mathrm{~N}+3 / 4 \mathrm{P}$

$\mathrm{T} 6=\mathrm{PGPR}-5+\mathrm{PSB}+3 / 4 \mathrm{~N}+3 / 4 \mathrm{P}$

$\mathrm{T} 7=\mathrm{PGPR}-1,2,3,4,5+\mathrm{PSB}+3 / 4 \mathrm{~N}+3 / 4 \mathrm{P}$

$\begin{array}{llllllll}\begin{array}{l}\text { Straw P } \\ \text { content (\%) }\end{array} & \begin{array}{l}\text { \% In- } \\ \text { crease }\end{array} & \begin{array}{l}\text { Grain P } \\ \text { content (\%) }\end{array} & \begin{array}{l}\text { \% In- } \\ \text { crease }\end{array} & \begin{array}{l}\text { Straw P } \\ \text { uptake }\end{array} & \begin{array}{l}\text { \% In- } \\ \text { crease }\end{array} & \begin{array}{l}\text { Grain P } \\ \text { uptake (\%) }\end{array} & \begin{array}{l}\text { \% In- } \\ \text { crease }\end{array} \\ 0.038 \mathrm{f} & ----- & 0.34 \mathrm{f} & ---- & 0.027 \mathrm{e} & ---- & 0.047 \mathrm{c} & ----- \\ 0.038 \mathrm{e} & 1.27 & 0.43 \mathrm{e} & 25.95 & 0.031 \mathrm{~d} & 15.45 & 0.094 \mathrm{a} & 34.59 \\ 0.039 \mathrm{~d} & 3.27 & 0.44 \mathrm{~b} & 30.75 & 0.033 \mathrm{~cd} & 20.63 & 0.076 \mathrm{~b} & 7.96 \\ 0.040 \mathrm{~b} & 5.93 & 0.44 \mathrm{c} & 29.78 & 0.034 \mathrm{bc} & 25.22 & 0.098 \mathrm{a} & 39.95 \\ 0.040 \mathrm{c} & 4.6 & 0.44 \mathrm{c} & 29.86 & 0.033 \mathrm{~cd} & 20.7 & 0.093 \mathrm{a} & 32.45 \\ 0.039 \mathrm{~d} & 3.27 & 0.44 \mathrm{~d} & 29.42 & 0.035 \mathrm{ab} & 29.11 & 0.075 \mathrm{~b} & 6.87 \\ 0.041 \mathrm{a} & 7.93 & 0.45 \mathrm{a} & 30.97 & 0.036 \mathrm{a} & 33.72 & 0.101 \mathrm{a} & 44.98\end{array}$

Table 5: Effect of plant growth promoting rbizobacteria on Agro-physiological traits of maize in field experiment.

Treatment Chlorophyll \% In- No. of \% In- Plant \% In- Earleaf \% In- Ear Inter- \% In- Flag \% Incontents crease leaves crease Height crease area crease node girth crease leaf area crease

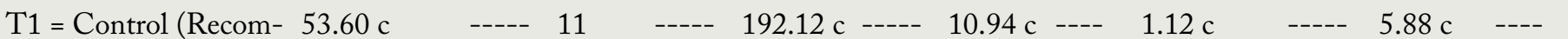
mended NP)

$\mathrm{T} 2=\mathrm{PGPR}+\mathrm{PSB}+3 / 4 \quad 56.26 \mathrm{~b} \quad \begin{array}{llllllllllll} & 4.96 & 16 & 45.45 & 194.58 \mathrm{~b} & 1.28 & 11.37 \mathrm{~b} & 3.86 & 1.35 \mathrm{~b} & 20.9 & 6.33 \mathrm{~b} & 7.65\end{array}$

$\mathrm{N}+3 / 4 \mathrm{P}$

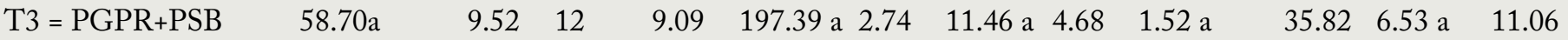

(Recommended NP)

Table 6: Effect of plant growth promoting rhizobacteria on contents and uptake of Phosphorous (gm plant-1) in maize plants in field experiment.

$\begin{array}{lllllllll}\text { Treatment } & \begin{array}{l}\text { Straw P con- } \\ \text { tent }(\%)\end{array} & \begin{array}{l}\text { \%n- } \\ \text { crease }\end{array} & \begin{array}{l}\text { Grain P } \\ \text { content (\%) }\end{array} & \begin{array}{l}\text { \% In- } \\ \text { crease }\end{array} & \begin{array}{l}\text { Straw P } \\ \text { uptake }\end{array} & \begin{array}{l}\text { \% In- } \\ \text { crease }\end{array} & \begin{array}{l}\text { Grain P } \\ \text { uptake (\%) }\end{array} & \begin{array}{l}\text { \% In- } \\ \text { crease }\end{array} \\ \text { T1 = Control (Recommended NP) } & 0.036 \mathrm{c} & ---- & 0.35 \mathrm{~b} & ----- & 1.55 \mathrm{c} & ----- & 8.48 \mathrm{c} & ----- \\ \mathrm{T} 2=\mathrm{PGPR}+\mathrm{PSB}+3 / 4 \mathrm{~N}+3 / 4 \mathrm{P} & 0.038 \mathrm{~b} & 6.22 & 0.35 \mathrm{~b} & 0.47 & 2.05 \mathrm{~b} & 32.38 & 11.49 \mathrm{~b} & 35.62 \\ \mathrm{~T} 3 \text { = PGPR+PSB (Recommended NP) } & 0.039 \mathrm{a} & 8.09 & 0.41 \mathrm{a} & 18.68 & 2.20 \mathrm{a} & 42.37 & 15.09 \mathrm{a} & 78.05\end{array}$

$\mathrm{N} 160$ and $\mathrm{P} 90 \mathrm{~kg} \mathrm{ha}^{-1}$ ) (Figure 3). Whereas PGPR 160 and $\mathrm{P} 90 \mathrm{~kg} \mathrm{ha}^{-1}$ ) (Table 5). and PSB with N and P @ 120 and P $67.5 \mathrm{~kg} \mathrm{ha}^{-1}$ showed 9\% increase over control (Recommended $\mathrm{N}$ 
Plant height $(\mathrm{cm})$

Increase of $2 \%$ plant heightwas recorded with combined application of PGPR, PSB and recommended $\mathrm{N}$ and $\mathrm{P} @ 160$ and $90 \mathrm{~kg} \mathrm{ha}^{-1}$ ) and increase in plant height was $1 \%$ with PGPR strains and PSB with low levels of nitrogen and phosphorus (@120 and P $67.5 \mathrm{~kg}$ ha

1) compared to control (Recommended N 160 and P $90 \mathrm{~kg} \mathrm{ha}{ }^{-1}$ ) (Figure 3, Table 5).

Ear leaf area $\left(\mathrm{cm}^{2}\right)$ : The data on ear leaf area showed significant increase in case of co-inoculation of PSB, PGPR and recommended N and P(@160 and $90 \mathrm{~kg} \mathrm{ha}^{-1}$ ) that was $4 \%$ superior over control (Recommended N 120 and P $62.5 \mathrm{~kg} \mathrm{ha}^{-1}$ ) (Figure 3). Inoculation of PGPR and PSB with nitrogen and phosphorus@120 and P $67.5 \mathrm{~kg} \mathrm{ha}^{-1}$ showed 3\% increase over control (Recommended 160 and P 90 $\left.\mathrm{kg} \mathrm{ha}{ }^{-1}\right)$ (Table 5).

\section{Ear internodes girth ( $\mathrm{mm}$ )}

Maximum ear internodes girth was recorded in case of application of PGPR and PSB with nitrogen and phosphorus (@ Recommended N 160 and P 90 kg ha 1) that was 35\% higher over control (Recommended $\mathrm{N} 160$ and $\mathrm{P} 90 \mathrm{~kg} \mathrm{ha}^{-1}$ ) (Figure 3). Co-inoculation of PGPR and PSB with N and P@ 120 and P $67.5 \mathrm{~kg} \mathrm{ha}$ 1) showed $20 \%$ increase than control (Recommended N 160 and $P 90 \mathrm{~kg} \mathrm{ha}^{-1}$ ) (Table 5).

Flag leaf area $\left(\mathbf{c m}^{2}\right)$ : The data on flag leaf area indicated significant $(\mathrm{P}<0.05)$ increase in case of co-inoculation of PGPR and PSB with N and P @ Recommended 160 and $90 \mathrm{~kg}$ ha-1 that was $11 \%$ higher over control (Recommended N 160 and P 90 $\mathrm{kg} \mathrm{ha} \mathrm{h}^{-1}$ ) (Figure 3). Inoculation of PGPR and PSB with $\mathrm{N}$ and $\mathrm{P} @ 120$ and $67.5 \mathrm{~kg} \mathrm{ha} \mathrm{k}^{-1}$ showed 7\% increase over control (Table 5).

\section{Plant analysis after harvest}

Straw phosphorus (\%): A considerable variation in straw phosphorus contents was observed with all the three treatments. Maximum increase of $8 \%$ in straw phosphorus was recorded by co-inoculation of PGPR and PSB with N and P @ Recommended 160 and $90 \mathrm{~kg} \mathrm{ha}{ }^{-1}$ over control (Recommended N 160 and P $90 \mathrm{~kg} \mathrm{ha}^{-1}$ ) (Figure 4). The application of PGPR and PSB with N and P (@120 and P 67.5 kg ha ${ }^{-1}$ ) also showed 6\% increase over control (Recommended N 160 and $P 90 \mathrm{~kg} \mathrm{ha}^{-1}$ ) (Table 6).

Grain phosphorus (\%): Like phosphorus content in straw, a significant $(\mathrm{P}<0.05)$ raise of $18 \%$ in phosphorus content in grain compared to control (Recommended N 160 and P 90kg ha ${ }^{-1}$ ) was observed in response to combined inoculation of PGPR and PSB with nitrogen and phosphorus at recommended levels (Figure 4). Slight increase of $0.47 \%$ was observed in case of application of PGPR and PSB with $\mathrm{N}$ and P @ Recommended 120 and $67.5 \mathrm{~kg} \mathrm{ha}{ }^{-1}$ over control (Recommended N 160 and P $90 \mathrm{~kg} \mathrm{ha}^{-1}$ ) (Table 6).
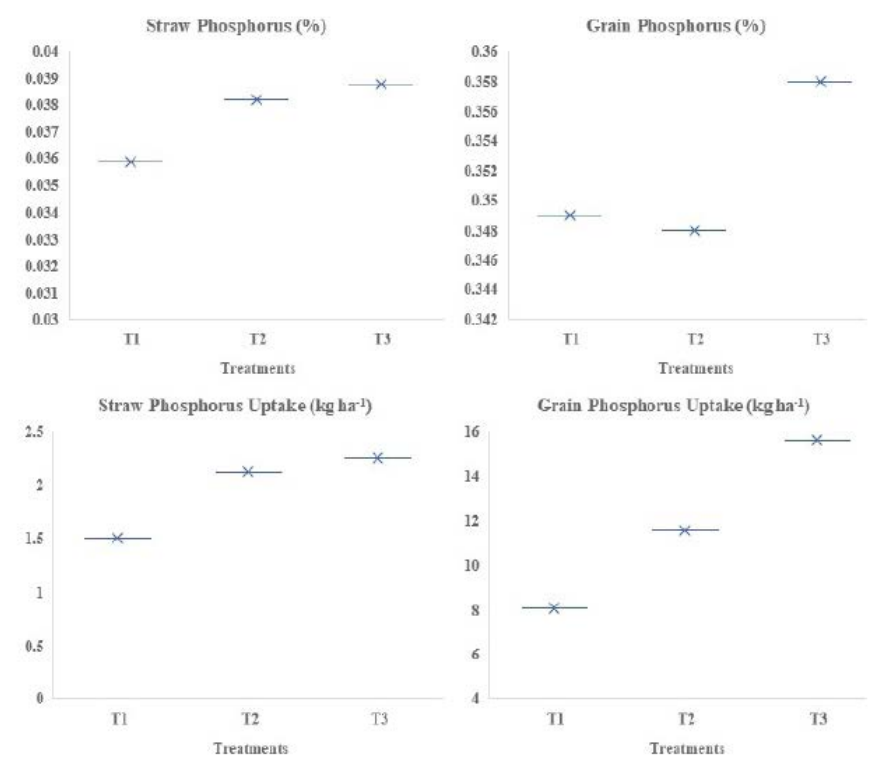

Figure 4: Effect of plant growth promoting Rhizobacteria on contents and uptake of Phosphorous (gm plant ${ }^{-1}$ ) in maize plants in pot experiment.

Straw phosphorus uptake ( $\left.\mathrm{kg} \mathrm{ha}^{-1}\right)$ : A considerable variation in straw phosphorus uptake was observed with all the three treatments. Maximum increase of $42 \%$ in straw phosphorus uptake was recorded in case of co-inoculation of PGPR and PSB with $\mathrm{N}$ and $\mathrm{P}$ @ Recommended 160 and $90 \mathrm{~kg} \mathrm{ha}{ }^{-1}$ over control (Recommended N 160 and P $90 \mathrm{~kg} \mathrm{ha}^{-1}$ ) (Figure 4). The application of PGPR and PSB with N and P (@ 120 and $\left.\mathrm{P} 67.5 \mathrm{~kg} \mathrm{ha}^{-1}\right)$ also showed 32\% increase over control (Recommended N 160 and P $90 \mathrm{~kg} \mathrm{ha}^{-1}$ ) (Table 6).

Grain phosphorus uptake ( $\left.\mathrm{kg} \mathrm{ha}^{-1}\right)$ : Like phosphorus uptake in straw, a significant $(\mathrm{P}<0.05)$ raise of $78 \%$ in phosphorus uptake in grain compared to control (Recommended N 160 and P $90 \mathrm{~kg} \mathrm{ha}^{-1}$ ) was observed in response to combined inoculation of PGPR and PSB with nitrogen and phosphorus at recommended levels (Figure 4). Significant increase of 35\% was observed in case of application of PGPR and PSB with $\mathrm{N}$ and $\mathrm{P} @ 120$ and $67.5 \mathrm{~kg} \mathrm{ha}{ }^{-1}$ over control 
(Recommended N 160 and P $90 \mathrm{~kg} \mathrm{ha}^{-1}$ ) (Table 6).

For optimum growth and yield of crops the nutrients must be available in adequate and balanced quantities. Soil is natural body having reserves of plant nutrients except nitrogen which is low in soil. However, these nutrient reserves for plants are mostly in unavailable forms. Nitrogen and phosphorus are the most important nutrients for plant growth and development. The use of nitrogenous and phosphatic fertilizers has increased more than nine and fourfold during the last few years (Vance, 2001). The intensive use of synthetic fertilizers in agriculture land is posing momentous threats to the environment (Yunlong et al., 2009). For soil fertility maintenance and to increase crop yield it is necessary to integrate nutrient management (Afzal et al., 2017). Soil microbes play a vital role in providing nutrients for growth and development of crop plants (Adesemoye et al., 2008, 2009; Berg, 2009). To sustain environment friendly crop production and to compensate synthetic fertilizers microbial inoculants are biological alternative (Dobbelaere et al., 2003). Combined use of microbial and synthetic fertilizers can be cost effective and more yields can be harvested from the soil. In this aspect, the present study was designed to draw out information on the integrated use of plant growth promoting rhizobacteria (PGPR) and PSB on growth, nutrient uptake, crop quality and yield of maize (Zea mays L.) with reduced synthetic fertilizer rates. The results attained from these investigations are discussed as follows.

In biogeochemical cycles soil bacteria are involved. For decades these have been used in crop production (Hayat et al., 2010). Plant growth promoting rhizobacteria (PGPR) with signal communication between host and plant and form colonization on root surface (Bianciotto et al., 2000). At low cost Nitrogen fixing bacteria could improve yield (Küçük and Kivanc, 2008). Interaction of PGPR with $\mathrm{C}_{3}$ and $\mathrm{C}_{4}$ plants (e.g., rice, wheat, maize, sugarcane and cotton) significantly increases their growth and yield (Kennedy et al., 2004). PGPR synthesized plant growth promoting substances that improved plant growth and PSB facilitated the more nutrient uptake from the soil rhizosphere (Fuhrmann and Wollum, 1989). Nitrogen and phosphorous availability and uptake was significantly increased with PGPR resulting in enhanced growth and yield of wheat but also have economic benefits (Sood et al., 2019).
Similarly, the solubilization of phosphate is equally important.Phosphate solubilizing bacteria(PSB) make available different forms of soil-bound phosphorus to crop plants (Hayat et al., 2010; Rodri冈guez and Fraga, 1999; Whitelaw, 1999). More phosphate is available to plants in sustainable and environment friendly manner by these bacteria (Khan et al., 2007). Application of phosphate solubilizing microorganisms significantly improves the growth, development and uptake of phosphorus by plants (Chen et al., 2006; Igual et al., 2001). Combined inoculation is more effective than single inoculation of microbes. (Rudresh et al., 2005) observed significant effect of combined inoculation of legumes with microbes on growth as compared to either single inoculations or un-inoculated control. Similar results were observed by (Khurana and Sharma, 2000). Ahmad et al. (2019) concluded significant increase in growth and nutritional value of maize and Mungbean with application of bacterial strains such as aryabhattai $\mathrm{S} 10$ and Bacillus subtilis.

The microbial strains used in pot experiment were first tested in laboratory. Results indicated that inoculation had a significant influence on shoot and root length, shoot and root fresh weight compared to un-inoculated control. PGPR and its combinations with AMF improve the NUE. With the combination of reduced RDF and inoculants plant height, shoot and root dry weight, yield, and uptake of nutrient were comparable to those with the full RDF without inoculums was reported by (Adesemoye et al., 2009). Effect of co-inoculation of PGPR and PSB on growth, yield and nutrient uptake of maize at low levels of nitrogen and phosphorus ( 90 and $50 \mathrm{mg} \mathrm{kg}^{-1}$ ) was studied in pot and field experiments. Application of microbes in conjunction with chemical fertilizers had significant influence on morphological characters and yield parameters of maize.

Combined inoculation of PGPR and PSB with reduced levels of NP resulted in significant difference in growth and yield of maize comparatively uninoculated. Physio-morphological parameters significantly increased due to combined application of PGPR and phosphate solubilizing bacteria compared to un-inoculated. Combined use of plant growth promoting rhizobacteria (PGPR) and phosphate solubilizing microorganisms was more effective than the single inoculation. Results are in accordance with the findings of (Rudresh et al., 2005) who reported significant effect of combined application of microbes 
on growth and development of legumes compared to either single inoculations or un-inoculated control. Similar results were also observed by (Khurana and Sharma, 2000). In the present research, co-inoculation significantly increased growth and yield contributing parameters over non-inoculated. These results are in confirmation with the findings of (Mirza et al., 2007; Yadegari and Rahmani, 2010; Zahir et al., 2010) whom observed the effects of inoculation on growth and yield of various field crops. (Zaidi, 1998; Garcia et al., 2004) also demonstrated that the combination of nitrogen fixing and phosphate solubilizing microbes observed significant difference in yield and yield components of crops.

Measurement of nitrogen and phosphorus content in plant can be a direct criterion to verify the efficiency of nitrogen fixing and phosphate solubilizing microbes, because of fixed nitrogen and increased available phosphorus ultimately leads to nitrogen and phosphorus accumulation in plant. Plant nutrient uptake i.e. phosphorus and nitrogen content in straw and grain were also enhanced by inoculation of PGPR and phosphate solubilizing bacteria. These findings are in agreement with those of (Rudresh et al., 2005) who reported that the combined inoculation of Rhizobium and PSB gave a higher nutrient uptake compared to single inoculation and un-inoculated control. Enhancement of nutrient uptake by plants with inoculation has also reported by many researchers (Ashrafi and Seiedi, 2010; Gholami et al., 2009; Nadeem et al., 2009; Yazdani et al., 2009) as compared to control without inoculation.

In addition, nutrient status i.e. nitrogen and phosphorus content of soil was improved by the simultaneous application of phosphate solubilizing and nitrogen fixing bacteria compared to single inoculation and un-inoculated control. Same results were observed by (Linu et al., 2009; Zaidi et al., 2003).

The co-inoculation of PGPR and PSB can significantly increase the yield/production of maize even using lower doses of nitrogen and phosphate fertilizers and then can contribute in the uplift of farmer's economic status and ultimately in the national economy. It can also improve the nutrient status/quality of maize. Therefore, their use should be recommended for maize cultivation.

\section{Author's Contribution}

Attique Ahmed: Conducted Research Trials, Data Collection, Manuscript Preparation.

Tariq Sultan: Ghulam Qadir: Research Supervision. Obaid Afzal: Data Compilation, Analysis and Manuscript preparation.

Mukhtar Ahmed: Data Analysis and Proof reading. Shamim-U1-Sibtain Shah and Muhammad Asif: Assistance in Research Execution.

Safdar Ali: Manuscript Preparation.

Muhammad Zeeshan Mehmood: Data Collection and Compilation, Manuscript Preparation.

\section{References}

Adesemoye, A., H. Torbert and J. Kloepper. 2008. Enhanced plant nutrient use efficiency with PGPR and AMF in an integrated nutrient management system. Can. J. Microbiol. 54: 876-886. https://doi.org/10.1139/W08-081

Adesemoye, A., H. Torbert and J. Kloepper. 2009. Plant growth-promoting rhizobacteria allow reduced application rates of chemical fertilizers. Microbial. Ecol. 58: 921-929. https://doi. org/10.1007/s00248-009-9531-y

Adesemoye, A.O. and J.W. Kloepper. 2009. Plantmicrobes interactions in enhanced fertilizeruse efficiency. Appl. Microbiol. Biotechnol. 85: 1-12. https://doi.org/10.1007/s00253-0092196-0

Afzal, O., M. Asif, M. Ahmed, F.K. Awan, M.A. Aslam, A. Zahoor, M. Bilal, F.A. Shaheen, M.A. Zulfiqar and N. Ahmed. 2017. Integrated Nutrient Management of Safflower (Carthamus tinctorius L.) under Rainfed Conditions. Am. J. Plant Sci. 8: 2208. https://doi.org/10.4236/ ajps.2017.89148

Ahmad, M., Z. Adil, A. Hussain, M.Z. Mumtaz, M. Nafees, I. Ahmad and M. Jamil. 2019. Potential of phosphate solubilizing Bacillus strains for improving growth and nutrient uptake in mungbean and maize crops. Pak. J. Agric. Sci. 56: 283-289.

Altomare, C., W. Norvell, T. Björkman and G. Harman.1999. Solubilization of phosphates and micronutrients by the plant-growth-promoting and biocontrol fungus Trichoderma harzianum Rifai 1295-22. Appl. Environ. Microbiol. 65: 2926-2933. https://doi.org/10.1128/ AEM.65.7.2926-2933.1999 
Antoun, H. 2001. Plant-Growth-Promoting Rhizobacteria. (Eds. S Brenner and J Miller. pp, 1477-1480). https://doi.org/10.1006/ rwgn.2001.1636

Antoun, H., C.J. Beauchamp, N. Goussard, R. Chabot and R. Lalande. 1998. Potential of Rhizobium and Bradyrhizobium species as plant growth promoting rhizobacteria on non-legumes: effect on radishes (Raphanus sativus L.). Plant Soil. 204: 57-67. https://doi. org/10.1007/978-94-017-2321-3_5

Ashrafi, V. and M.N. Seiedi. 2011. Influence of different plant densities and plant growth promoting rhizobacteria (pgpr) on yield and yield attributes of corn (Zea maize L.). Recent Res. Sci. Technol. 3(1): 63-66.

Bashan, Y. and L.E.De-Bashan.2010. Chapter twohow the plant growth-promoting bacterium Azospirillum promotes plant growth - a critical assessment. Adv. Agron. 108: 77-136. https:// doi.org/10.1016/S0065-2113(10)08002-8

Belimov, A., A. Kojemiakov and C.N. Chuvarliyeva. 1995. Interaction between barley and mixed cultures of nitrogen fixing and phosphatesolubilizing bacteria. Plant Soil. 173: 29-37. https://doi.org/10.1007/BF00155515

Berg, G. 2009. Plant-microbe interactions promoting plant growth and health: perspectives for controlled use of microorganisms in agriculture. Appl. Microbiol. Biotechnol. 84: 11-18. https://doi.org/10.1007/s00253-0092092-7

Bhattacharjee, R.B., A.Singh and S.Mukhopadhyay. 2008. Use of nitrogen-fixing bacteria as biofertiliser for non-legumes: prospects and challenges. Appl. Microbiol. Biotechnol. 80: 199-209. https://doi.org/10.1007/s00253-008$1567-2$

Bianciotto, V., E. Lumini, L. Lanfranco, D. Minerdi, P. Bonfante and S. Perotto. 2000. Detection and identification of bacterial endosymbionts in arbuscular mycorrhizal fungi belonging to the family Gigasporaceae. Appl. Environ. Microbiol. 66: 4503-4509. https://doi.org/10.1128/ AEM.66.10.4503-4509.2000

Cakmakçi, R., F. Dönmez, A. Aydın and F. Şahin. 2006. Growth promotion of plants by plant growth-promoting rhizobacteria under greenhouse and two different field soil conditions. Soil Biol. Biochem. 38: 1482-1487. https://doi.org/10.1016/j.soilbio.2005.09.019
Chaudhry, A.R. 1983. Maize in Pakistan, Punjab Agricultural Research Coordination Board, University of Agriculture.

Chen, Y., P. Rekha, A. Arun, F. Shen, W.A. Lai and C. Young. 2006. Phosphate solubilizing bacteria from subtropical soil and their tricalcium phosphate solubilizing abilities. Appl. Soil Ecol. 34: 33-41. https://doi.org/10.1016/j. apsoil.2005.12.002

Cherif, H., M. Neifar, H. Chouchane, A. Soussi, C. Hamdi,A.Guesmi,I.Fhoula,A.Najjari,R.Ferjani and M. Mahjoubi.2018. Extremophile diversity and biotechnological potential from desert environments and saline systems of southern Tunisia. In Extremophiles, CRC Press. pp. 3364. https://doi.org/10.1201/9781315154695-3

Choudhary, D.K. and A. Varma. 2016. Microbialmediated induced systemic resistance in plants, Springer. https://doi.org/10.1007/978-981-100388-2

Dobbelaere, S., J. Vanderleyden and Y. Okon. 2003. Plant growth-promoting effects of diazotrophs in the rhizosphere. Crit. Rev. Plant Sci. 22: 107149. https://doi.org/10.1080/713610853

Estrada-De Los Santos, P., R.O. Bustillos-Cristales and J. Caballero-Mellado. 2001. Burkholderia, a genus rich in plant-associated nitrogen fixers with wide environmental and geographic distribution. Appl. Environ. Microbiol. 67: 2790-2798. https://doi.org/10.1128/ AEM.67.6.2790-2798.2001

Flessa, H., R. Ruser, P. Dörsch, T. Kamp, M. Jimenez,J.Munch and F.Beese.2002.Integrated evaluation of greenhouse gas emissions ( $\mathrm{CO} 2$, $\mathrm{CH} 4, \mathrm{~N} 2 \mathrm{O}$ ) from two farming systems in southern Germany. Agric. Ecosyst. Environ. 91: 175-189. https://doi.org/10.1016/S01678809(01)00234-1

Fuentes-Ramírez, L.E., R. Bustillos-Cristales, A. Tapia-Hernández, T. Jiménez-Salgado, E.T. Wang, E. Martínez-Romero and J. CaballeroMellado. 2001. Novel nitrogen-fixing acetic acid bacteria, Gluconacetobacter jobannae sp. nov. and Gluconacetobacter azotocaptans sp. nov., associated with coffee plants. Int. J. Syst. Evolut. Microbiol. 51: 1305-1314. https://doi. org/10.1099/00207713-51-4-1305

Fuhrmann, J. and A. Wollum. 1989. Nodulation competition among Bradyrbizobium japonicum strains as influenced by rhizosphere bacteria and iron availability. Biol. Fert. Soils. 7: 108- 
112. https://doi.org/10.1007/BF00292567

Garcia, L. J. A., Probanza, A., Ramos, B., Barriuso, J., and Gutierrez Manero, F. 2004. Effects of inoculation with plant growth promoting rhizobacteria (PGPRs) and Sinorbizobium fredii on biological nitrogen fixation, nodulation and growth of Glycine max cv. Osumi. Plant Soil. 267: 143-153. https://doi.org/10.1007/s11104005-4885-5

Gee, G. W., and Bauder, J. W. 1986. Particle-size analysis. Methods of soil analysis: Part 1 Physical and mineralogical methods, 5, 383-411.

Gholami,A., S. Shahsavani and S.Nezarat.2009.The effect of plant growth promoting rhizobacteria (PGPR) on germination, seedling growth and yield of maize. Int. J. Biol. Life Sci. 1: 35-40. https://doi.org/10.3923/pjbs.2009.26.32

Glick, B. and J. Pasternak. 2003. Plant growth promoting bacteria. Mol. Biol. Principles Appl. Recomb. DNA, pp. 436-54.

Haji, M., R. Ahmed and A. Ghafoor. 2008. Production potential of three maize hybrids as influences by varying plant density. Pak. J. Agric. Sci. 45: 413-417.

Hayat, R., S. Ali, U. Amara, R. Khalid and I. Ahmed. 2010. Soil beneficial bacteria and their role in plant growth promotion: a review. Ann. Microbiol. 60: 579-598. https://doi. org/10.1007/s13213-010-0117-1

Hussain, I., M. Ahsan, M. Saleem and A. Ahmad. 2009. Gene action studies for agronomic traits in maize under normal and water stress conditions. Pak. J. Agric. Sci. 46: 108-112.

Igual, J., A. Valverde, E. Cervantes and E. Velázquez. 2001. Phosphate-solubilizing bacteria as inoculants for agriculture: use of updated molecular techniques in their study. Agron. 21: 561-568. https://doi.org/10.1051/ agro:2001145

Jha, B., M.C. Thakur, I. Gontia, V. Albrecht, M. Stoffels, M. Schmid and A. Hartmann. 2009. Isolation, partial identification and application of diazotrophic rhizobacteria from traditional Indian rice cultivars. Eur. J. Soil Biol. 45: 62-72. https://doi.org/10.1016/j.ejsobi.2008.06.007

Kennedy, I.R., A. Choudhury and M.L. Kecskés. 2004. Non-symbiotic bacterial diazotrophs in crop-farming systems: can their potential for plant growth promotion be better exploited? Soil Biol. Biochem. 36: 1229-1244. https://doi. org/10.1016/j.soilbio.2004.04.006
Khalid,A.,M.Arshad and Z.A.Zahir.2003. Growth and yield response of wheat to inoculation with auxin producing plant growth promoting rhizobacteria. Pak. J. Bot. 35: 483-498.

Khan, M.S., A. Zaidi and P.A. Wani. 2007. Role of phosphate-solubilizing microorganisms in sustainable agriculture-a review. Agron. Sustainable Dev. 27: 29-43. https://doi. org/10.1051/agro:2006011

Khurana, A. and P. Sharma. 2000. Effect of dual inoculation of phosphate solubilizing bacteria, Bradyrhizobium sp.(cicer) and phosphorus on nitrogen fixation and yield of chickpea. Indian J. Pulses Res. 13: 66-67.

Kloepper, J.W., J. Leong, M. Teintze and M.N. Schroth. 1980. Pseudomonas siderophores: a mechanism explaining disease-suppressive soils. Curr. Microbiol. 4: 317-320. https://doi. org/10.1007/BF02602840

Küçük, Ç. and M. Kivanc. 2008. Preliminary characterization of Rhizobium strains isolated from chickpea nodules. Afr. J. Biotechnol. 7: 772-775

Kumari, B., M. Mallick, M.K. Solanki, A.C. Solanki, A. Hora and W. Guo. 2019. Plant growth promoting rhizobacteria (PGPR): modern prospects for sustainable agriculture. In Plant Health Under Biotic Stress, Springer. pp. 109-127. https://doi.org/10.1007/978-981-136040-4_6

Lavakush, J. Yadav and J.P. Verma, 2012. Isolation and Characterization of Effective Plant Growth Promoting Rhizobacteria from Rice Rhizosphere of Indian Soil. Asian J. Biol. Sci., 5: 294-303. https://doi.org/10.3923/ ajbs.2012.294.303

Linu, M., J. Stephen and M. Jisha. 2009. Phosphate solubilizing Gluconacetobacter sp., Burkholderia $s p$. and their potential interaction with cowpea (Vigna unguiculata (L.) Walp.). Int. J. Agric. Res. 4: 79-87. https://doi.org/10.3923/ ijar.2009.79.87

Mirza, B.S., M.S. Mirza, A. Bano and K.A. Malik. 2007. Coinoculation of chickpea with Rhizobium isolates from roots and nodules and phytohormone-producing Enterobacter strains. Anim. Prod. Sci. 47: 1008-1015. https://doi. org/10.1071/EA06151

Mirza, M.S., S. Mehnaz, P. Normand, C. PrigentCombaret, Y. Moënne-Loccoz, R. Bally and K.A. Malik. 2006. Molecular characterization 
and PCR detection of a nitrogen-fixing Pseudomonas strain promoting rice growth. Biol. Fert. Soils. 43: 163-170. https://doi. org/10.1007/s00374-006-0074-9

Nadeem, S.M., Z.A. Zahir, M. Naveed and M. Arshad. 2009. Rhizobacteria containing ACCdeaminase confer salt tolerance in maize grown on salt-affected fields. Can. J. Microbiol. 55: 1302-1309. https://doi.org/10.1139/W09-092

Patten, C.L. and B.R. Glick. 1996. Bacterial biosynthesis of indole-3-acetic acid. Can. J. Microbiol. 42: 207-220. https://doi. org/10.1139/m96-032

Pradhan, N. and L. Sukla. 2006. Solubilization of inorganic phosphates by fungi isolated from agriculture soil. Afr. J. Biotechnol. 5: 850-854

Reinhold-Hurek, B., T. Hurek, M. Gillis, B. Hoste, M. Vancanneyt, K. Kersters and J. De Ley. 1993. Azoarcus gen. nov., nitrogenfixing proteobacteria associated with roots of Kallar grass (Leptochloa fusca (L.) Kunth), and description of two species, Azoarcus indigens sp. nov. and Azoarcus communis sp. nov. Int. J. Syst. Evolut. Microbiol. 43: 574-584. https:// doi.org/10.1099/00207713-43-3-574

Rodríguez, H. and R. Fraga. 1999. Phosphate solubilizing bacteria and their role in plant growth promotion. Biotechnol. Adv. 17: 319-339. https://doi.org/10.1016/S07349750(99)00014-2

Rudresh, D., M. Shivaprakash and R. Prasad. 2005. Effect of combined application of Rhizobium, phosphate solubilizing bacterium and Trichoderma spp. on growth, nutrient uptake and yield of chickpea (Ciceraritenium L.). Appl. Soil Ecol. 28: 139-146. https://doi. org/10.1016/j.apsoil.2004.07.005

Ryan, J., G. Estefan and A. Rashid. 2007. Soil and plant analysis laboratory manual, ICARDA.

Sindhu, S., S. Gupta and K. Dadarwal. 1999. Antagonistic effect of Pseudomonas spp. on pathogenic fungi and enhancement of growth of green gram (Vigna radiata). Biol. Fertil. Soils. 29: 62-68. https://doi.org/10.1007/ s003740050525

Sood, G., R. Kaushal, G. Panwar and M. Dhiman. 2019. Effect of Indigenous Plant GrowthPromoting Rhizobacteria on Wheat (Triticum Aestivum L.) Productivity and Soil Nutrients. Commun. Soil Sci. Plant Anal. 50: 141-152. https://doi.org/10.1080/00103624.2018.15562
82

Steel, R.G. and J.H. Torrie. 1980. Principles and procedures of statistics, a biometrical approach, McGraw-Hill Kogakusha, Ltd.

Van Der Heijden, M.G., R.D. Bardgett and N.M. Van Straalen. 2008. The unseen majority: soil microbes as drivers of plant diversity and productivity in terrestrial ecosystems. Ecol. Lett. 11: 296-310. https://doi.org/10.1111/j.14610248.2007.01139.x

Vance, C.P. 2001. Symbiotic nitrogen fixation and phosphorus acquisition. Plant nutrition in a world of declining renewable resources. Plant Physiol. 127: 390-397. https://doi.org/10.1104/ pp.010331

Vessey, J.K. 2003. Plant growth promoting rhizobacteria as biofertilizers. Plant Soil. 255: 571-586. https://doi. org/10.1023/A:1026037216893

Whitelaw, M.A. 1999. Growth promotion of plants inoculated with phosphate-solubilizing fungi. Adv. Agron. 69: 99-151. https://doi. org/10.1016/S0065-2113(08)60948-7

Wu, S., Z. Cao, Z. Li, K. Cheung and M. Wong. 2005. Effects of biofertilizer containing $\mathrm{N}$-fixer, $\mathrm{P}$ and $\mathrm{K}$ solubilizers and AM fungi on maize growth: a greenhouse trial. Geoderma. 125: 155-166. https://doi.org/10.1016/j. geoderma.2004.07.003

Yadegari, M. and H.A. Rahmani. 2010. Evaluation of bean (Phaseolus vulgaris) seeds inoculation with Rhizobium phaseoli and plant growth promoting Rhizobacteria (PGPR) on yield and yield components. Afr. J. Agric. Res. 5: 792-799.

Yang, J., J.W. Kloepper and C.M. Ryu. 2009. Rhizosphere bacteria help plants tolerate abiotic stress. Trends Plant Sci. 14: 1-4. https:// doi.org/10.1016/j.tplants.2008.10.004

Yazdani, M., M.A. Bahmanyar, H. Pirdashti and M.A. Esmaili. 2009. Effect of phosphate solubilization microorganisms (PSM) and plant growth promoting rhizobacteria (PGPR) on yield and yield components of corn (Zea mays L.). Proc. World Acad. Sci. Eng. Technol. 37: 90-92.

Yunlong, Y., C. Xiaoqiang, P. Guohui, Y. Xiang and F. Hua. 2009. Effects of repeated applications of fungicide carbendazim on its persistence and microbial community in soil. J. Environ. Sci. 21: 179-185. https://doi.org/10.1016/S10010742(08)62248-2 
Zahir, Z.A., H. Yasin, M. Naveed, M. Anjum and M. Khalid. 2010. L-tryptophan application enhances the effectiveness of rhizobium inoculation for improving growth and yield of mungbean (Vigna radiata (L.) Wilczek). Pak. J. Bot. 42: 1771-1780.

Zaidi, A. 1998. Synergistic interactions of nitrogen fixing microorganisms with phosphate mobilizing microorganisms.

Zaidi, A., M.S. Khan and M.Amil.2003. Interactive effect of rhizotrophic microorganisms on yield and nutrient uptake of chickpea (Cicer arietinum L.). Eur. J. Agron. 19: 15-21. https:// doi.org/10.1016/S1161-0301(02)00015-1 